\title{
Microbial community of predatory bugs of the genus Macrolophus (Hemiptera: Miridae)
}

\author{
Thijs Machtelinckx', Thomas Van Leeuwen', Tom Van De Wiele², Nico Boon², Winnok H De Vos ${ }^{3,4}$, \\ Juan-Antonio Sanchez ${ }^{5}$, Mauro Nannini ${ }^{6}$, Godelieve Gheysen ${ }^{7}$, Patrick De Clercq ${ }^{1 *}$
}

\begin{abstract}
Background: The predatory mirids of the genus Macrolophus are key natural enemies of various economically important agricultural pests. Both M. caliginosus and M. pygmaeus are commercially available for the augmentative biological control of arthropod pests in European greenhouses. The latter species is known to be infected with Wolbachia -inducing cytoplasmic incompatibility in its host- but the presence of other endosymbionts has not been demonstrated. In the present study, the microbial diversity was examined in various populations of $M$. caliginosus and M. pygmaeus by $16 \mathrm{~S}$ rRNA sequencing and denaturing gradient gel electrophoresis.

Results: Besides Wolbachia, a co-infection of 2 Rickettsia species was detected in all M. pygmaeus populations. Based on a concatenated alignment of the 16S rRNA gene, the gltA gene and the coxA gene, the first is phylogenetically related to Rickettsia bellii, whereas the other is closely related to Rickettsia limoniae. All M. caliginosus populations were infected with the same Wolbachia and limoniae-like Rickettsia strain as M. pygmaeus, but did not harbour the bellii-like Rickettsia strain. Interestingly, individuals with a single infection were not found. A PCR assay on the ovaries of $M$. pygmaeus and $M$. caliginosus indicated that all endosymbionts are vertically transmitted. The presence of Wolbachia and Rickettsia in oocytes was confirmed by a fluorescence in situ hybridisation. A bio-assay comparing an infected and an uninfected M. pygmaeus population suggested that the endosymbionts had minor effects on nymphal development of their insect host and did not influence its fecundity.

Conclusion: Two species of the palaearctic mirid genus Macrolophus are infected with multiple endosymbionts, including Wolbachia and Rickettsia. Independent of the origin, all tested populations of both M. pygmaeus and M. caliginosus were infected with three and two endosymbionts, respectively. There was no indication that infection with endosymbiotic bacteria had a fitness cost in terms of development and fecundity of the predators.
\end{abstract}

\section{Background}

In recent years, an increasing number of endosymbiotic bacteria have been detected in arthropods, often having intimate associations with their host. In some cases, these bacteria are obligatory for the survival and development of their host, providing them with essential nutrients $[1,2]$, while other endosymbionts are facultative and benefit their hosts' fitness by protecting them from parasites and diseases [3]. However, some arthropod endosymbionts are considered as 'reproductive parasites' [4]. These parasites manipulate the

\footnotetext{
* Correspondence: Patrick.DeClercq@ugent.be

'Laboratory of Agrozoology, Department of Crop Protection, Faculty of

Bioscience Engineering, Ghent University, Ghent, Belgium

Full list of author information is available at the end of the article
}

reproduction of their host to promote their own propagation, but these alterations may affect the fitness of their host [5].

The best studied and most widely spread arthropod endosymbiont is Wolbachia, an obligate intracellular Alpha-proteobacterium that infects approximately $66 \%$ of all insects [6]. Wolbachia alters its host in various ways, of which cytoplasmic incompatibility $(\mathrm{CI})$ is probably most studied [7]. Cytoplasmic incompatibility occurs when an uninfected female mates with an infected male (unidirectional CI) or when an infected female mates with an infected male bearing another Wolbachia-strain (bidirectional CI). This cross results in embryonic death, while all other crosses produce normal progeny. Other manipulations of Wolbachia are male

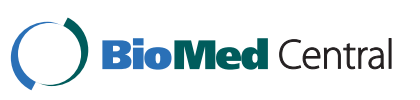


killing, in which infected male embryos die [8], parthenogenesis, in which nonfertilized infected mothers only produce infected female offspring [9] and feminization, in which genetic males are converted into fertile females [10]. In rare cases, Wolbachia is obligate for its insect host: in the parasitoid wasp Asobara tabida, the bacterium is necessary for oogenesis completion [11].

Besides Wolbachia, a wide range of other inherited bacteria are currently being investigated. One of these symbionts, Cardinium, [12] does not infect as many arthropods as Wolbachia, but can affect its host almost as strikingly by causing $\mathrm{CI}$, parthenogenesis and feminization [13-15]. Other important endosymbionts manipulating the reproduction of their host include Spiroplasma, Arsenophonus, Flavobacterium and Rickettsia.

Insights into the importance of Rickettsia as a reproductive parasite are increasing rapidly [16]. Rickettsia bacteria are Alpha-proteobacteria closely related to $\mathrm{Wol}$ bachia and are best known as arthropod-borne vertebrate pathogens. One Rickettsia is a known plant pathogen, causing papaya bunchy top disease vectored by a leafhopper [17]. In recent years, however, an increasing amount of non-pathogenic 'arthropod Rickettsia' have been discovered, lacking a secondary host. These endosymbionts are dispersed throughout different arthropod classes, including a wide range of insect species [18]. Although their biological role needs to be largely elucidated, these 'arthropod Rickettsia' can act as reproductive parasites. In the ladybirds Adalia bipunctata and Adalia decempunctata as well as in the buprestid beetle Brachys tessellatus the endosymbiont has been demonstrated to cause male embryonic lethality [19-21]. Further, parthenogenesis induction is described in the parasitoid wasps Pnigalio soemius and Neochrysocharis formosa [22,23]. Perotti et al. [24] also found evidence of an obligate Rickettsia in the booklouse Liposcelis bostrychophila with a key role for egg production.

Endosymbiotic bacteria have been described in harmful as well as beneficial arthropods. The presence and role of endosymbionts are well studied in certain groups of beneficial arthropods, including hymenopteran parasitoids and coccinellid predators [25]. However, relatively few studies have focused on the endosymbiotic bacteria of predatory Heteroptera (true bugs), despite their economic importance as biological control agents of agricultural pests [26]. In the present study, the microbial community of Macrolophus spp. is examined. Macrolophus is a genus of polyphagous mirid predators commonly used in European greenhouses for the biological control of whiteflies, spider mites, thrips, aphids, and leaf miners $[27,28]$. The two major species that have been used in commercial biological control are M. caliginosus and M. pygmaeus. It has been established that
M. pygmaeus carries Wolbachia, which induces strong $\mathrm{CI}$ in its host and may thus have a substantial impact on the practical use of the predator in programmes of biological pest control [29]. However, other endosymbiotic bacteria have not been demonstrated to infect Macrolophus spp. The microbial population of M. pygmaeus and M. caliginosus was examined by $16 S$ rRNA gene sequencing and denaturing gradient gel electrophoresis (PCR-DGGE). The latter technique has been used to characterize complex bacterial compositions of environmental samples [30,31], but also proved useful to explore bacterial communities in arthropods [32-34]. Furthermore, a fluorescence in situ hybridization (FISH) analysis was performed to visualize the co-localization of different endosymbionts. Improving our understanding of the composition and functions of the endosymbiotic community of these predatory insects may contribute to optimizing their use as natural enemies of agricultural pests.

\section{Methods}

\section{Insect populations}

Adults of different Macrolophus populations were collected from sites in Greece, Spain and Italy (Table 1) and preserved in $70 \%$ ethanol. A laboratory strain of $M$. pygmaeus originating from Koppert B.V. (Berkel en Rodenrijs, The Netherlands) and an endosymbiont-free strain (cured by tetracycline) which originated from the same stock culture [29] was maintained in the Laboratory of Agrozoology of Ghent University since 2006 and 2008, respectively. The endosymbiont-free strain was cured by feeding it on an artificial diet containing tetracycline for 13 generations [29]. From the next generation on, this population was supplied with frozen eggs of the Mediterranean flour moth Ephestia kuehniella (also from Koppert B.V). A PCR-assay using endosymbiont-specific primers (Table 2) was performed (every 3 to 4 generations) to ensure its cured status. A laboratory population of $M$. caliginosus was established based on field collected individuals in Santa Margherita di Pula, Sardinia, Italy.

Both Macrolophus spp. were reared in Plexiglas cylinders $\left(9 \mathrm{~cm}\right.$ diameter, $3.5 \mathrm{~cm}$ high) at $23^{\circ} \mathrm{C}, 65 \%$ relative humidity and a $16: 8$ light : dark (L : D) h photoperiod. A small bell pepper plant (Capsicum annuum L. cv. California Wonder) was used as an oviposition substrate and a source of moisture [28]. The predator was fed with frozen E. kuehniella eggs which were replenished every 2 days.

\section{DNA extraction}

Male and female adults were surface sterilized in $70 \%$ ethanol and rinsed with sterilized water. Individuals from laboratory-reared populations were starved for $24 \mathrm{~h}$ before extraction to allow voiding of the gut content. A 
Table 1 Macrolophus spp. populations used in this study.

\begin{tabular}{|c|c|c|c|c|}
\hline Strain name & Origin & Host plant & Species & Accession no \\
\hline AmaDV & Amaliada, Greece & Dittrichia viscosa & M. caliginosus & HE583190 \\
\hline AmaSN & Amaliada, Greece & Solanum nigrum & M. pygmaeus & HE583191 \\
\hline Esp & La Vereda, Murcia, Spain & Solanum lycopersicum & M. pygmaeus & HE583192 \\
\hline Grec & Thessaloniki, Greece & S. nigrum & M. pygmaeus & HE583193 \\
\hline KorDV & Korinthos, Greece & D. viscosa & M. caliginosus & HE583194 \\
\hline KorSN & Korinthos, Greece & S. nigrum & M. pygmaeus & HE583195 \\
\hline $\mathrm{Kp}$ & Laboratory strain, originating from Koppert BV & Capsicum annuum & M. pygmaeus & HE583196 \\
\hline KypDV & Kyparissia, Greece & D. viscosa & M. caliginosus & HE583197 \\
\hline KypSN & Kyparissia, Greece & S. nigrum & M. pygmaeus & HE583198 \\
\hline Sard & Santa Margherita di Pula, Sardinia, Italy & D. viscosa & M. caliginosus & HE583199 \\
\hline Skyd & Skydra, Greece & S. nigrum & M. pygmaeus & HE583200 \\
\hline ThivDV & Thiva, Greece & D. viscosa & M. pygmaeus & HE583201 \\
\hline
\end{tabular}

DNeasy Blood and Tissue Kit (Qiagen, Venlo, The Netherlands) was used to extract the DNA, applying the manufacturer's instructions for gram-positive bacteria. A no-template control and DNA from the cured strain was also included in each DNA-extraction to prevent false positive results in the PCR and PCR-DGGE reactions. DNA was eluted in $50 \mu \mathrm{l}$ of DNeasy buffer AE (10 mM Tris-Cl, 0.5 mM EDTA, pH 9.0) after which DNAquality was checked by staining a $1 \%$ agarose gel in 0.5 $x$ TAE with ethidium bromide and visualizing with UVillumination (Bio-Rad Gel Doc XR System, 254 nm; Bio-
Rad, Hercules, CA, USA). DNA-concentration was measured with the Nanodrop ND-1000 spectrophotometer (Thermo Fisher Scientific, Wilmington, DE, USA).

Ovaries and guts were dissected in a vertical laminar flow and washed twice with sterilized water under a stereomicroscope. Between 20 to 30 guts or ovaries were used for the DNA-extraction.

\section{Primers}

All primers used in this study are listed in Table 2 . Macrolophus species determination was clarified by

Table 2 Primer sequences used in this study for PCR and PCR-DGGE. The accession numbers point to the genes that were used to construct the gene specific primers.

\begin{tabular}{|c|c|c|c|}
\hline Targeted gene & Name & Sequence & Accession number/ Reference \\
\hline \multirow[t]{3}{*}{ Cytochrome b gene of Macrolophus spp. } & CB-1 & 5'- TATGTACTACCATGAGGACAAATATC - 3' & [68] \\
\hline & CB-2 & 5'- ATTACACCTCCTAATTTATTAGGAAT - $3^{\prime}$ & [68] \\
\hline & Lau1F & 5'- AATGGCTATGAGGGGGRTTCTC -3' & [35] \\
\hline \multirow[t]{4}{*}{ General primers for the bacterial 165 rRNA gene } & $27 \mathrm{~F}$ & 5'- AGAGTTTGATCMTGGCTCAG -3' & [43] \\
\hline & $806 R$ & 5'- GGACTACCAGGGTATCTAAT -3' & [69] \\
\hline & $1492 \mathrm{R}$ & 5'- TACGGYTACCTTGTTACGACTT -3' & [43] \\
\hline & $1525 R$ & 5'- AAAGGAGGTGWTCCARC - $3^{\prime}$ & [69] \\
\hline \multirow[t]{4}{*}{ V3 region of the bacterial 165 rRNA gene* } & $338 \mathrm{~F}^{\mathrm{GC}}$ & 5'- CGCCCGCCGCGCGCGGC & [43] \\
\hline & & GGGGCGGGGGCACGGGGGG & \\
\hline & & ACTCCTACGGGAGGCAGCAG -3' & \\
\hline & $518 \mathrm{R}$ & 5'- ATTACCGCGGCTGCTGG -3' & [30] \\
\hline \multirow[t]{2}{*}{ wsp gene of Wolbachia } & wsp81F & 5'- TGGTCCAATAAGTGATGAAGAAAC - $3^{\prime}$ & [70] \\
\hline & wsp691R & 5'- AAAAATTAAACGCTACTCCA -3' & {$[70]$} \\
\hline 165 rRNA gene of $R$. limoniae and $R$. bellii & Rick-1F & 5'- ATACCGAGTGRGTGAYGAAG -3' & AF322442, L36103 \\
\hline $16 S$ rRNA gene of $R$. limoniae & Ricklimoniae-F & 5'- CGGTACCTGACCAAGAAAGC -3' & AF322442 \\
\hline $16 S$ rRNA gene of $R$. bellii & Rickbellii-R & 5'- TCCACGTCGCCGTCTTGC - -3' & L36103 \\
\hline \multirow[t]{2}{*}{ Citrate synthase gene (gltA) } & gltA133f & 5'- GGTTTTATGTCTACTGCTTCKTG -3' & [17] \\
\hline & gltA1197r & 5'- CATTTCTTTCCATTGTGCCATC- 3' & [17] \\
\hline \multirow[t]{2}{*}{ Cytochrome c oxidase gene (coxA) } & CoxA322f & 5'- GGTGCTCCTGATATGGCATT -3' & [18] \\
\hline & CoxA1413r & 5'- CATATTCCAACCGGCAAAAG -3' & [18] \\
\hline \multirow[t]{2}{*}{ p-GEMT cloning vector } & $\mathrm{T7}$ & 5'- TAATACGACTCACTATAGGG -3' & Promega \\
\hline & SP6 & 5'- CTATTTAGGTGACACTATAG -3' & Promega \\
\hline
\end{tabular}

*The sequence of the GC-clamp is indicated in bold 
targeting a part of the cytochrome b gene [35]. The bacterial community was characterized in $M$. pygmaeus by using universal primers 27F-806R and 27F-1525R which amplify the bacterial $16 S$ rRNA gene. Specific Rickettsiaprimers targeting the $16 S$ rRNA gene were constructed using primer3 [36] as implemented in primer-BLAST [http://www.ncbi.nlm.nih.gov/]. The primer pair Rick1F1492R amplified a part of both Rickettsia species, whereas the Wolbachia primers were based on the wsp gene (Table 2).

\section{PCR and cloning}

All PCR reactions were executed using a Biometra TProfessional Standard Gradient Thermocycler (Westburg, Leusden, The Netherlands) in $50 \mu$ l containing 2 $\mathrm{mM} \mathrm{MgCl}, 0.2 \mathrm{mM}$ deoxynucleotide triphosphate (dNTP) mix (Invitrogen, Carlsbad, CA, USA), $2 \mathrm{mM}$ $\mathrm{MgCl}_{2}, 5 \mu \mathrm{l}$ 10x PCR-buffer (Invitrogen), $1 \mathrm{U}$ Taq DNA polymerase (Invitrogen) and $1 \mu \mathrm{l}$ DNA template (between 100 and $200 \mathrm{ng} / \mu \mathrm{l}$ ). PCR for species determination was executed under the following conditions [35]: $5 \mathrm{~min}$ at $95^{\circ} \mathrm{C}, 36$ cycles of $45 \mathrm{~s}$ at $95{ }^{\circ} \mathrm{C}, 30 \mathrm{~s}$ at $50{ }^{\circ} \mathrm{C}, 30 \mathrm{~s}$ at $72{ }^{\circ} \mathrm{C}$ and a final extension of $10 \mathrm{~min}$ at $72{ }^{\circ} \mathrm{C}$. Amplification conditions for all other PCR reactions were $2 \mathrm{~min}$ at $94{ }^{\circ} \mathrm{C}, 35$ cycles of $30 \mathrm{~s}$ at $94{ }^{\circ} \mathrm{C}, 45$ $\mathrm{s}$ at $54{ }^{\circ} \mathrm{C}, 1 \mathrm{~min} 30 \mathrm{~s}$ at $72{ }^{\circ} \mathrm{C}$ and a final elongation step of $5 \mathrm{~min}$ at $72{ }^{\circ} \mathrm{C}$. PCR products were electrophoresed on a $1 \%$ agarose gel in $0.5 \mathrm{x}$ TAE-buffer and after staining with ethidium bromide visualized under UVlight (Bio-Rad Gel Doc XR System, $254 \mathrm{~nm}$ ). PCR products were purified using the EZNA Cycle Pure Kit (Omega Bio-Tek Inc., Norcross, GA, USA). If necessary, purified PCR products were cloned into the pGEM-T Vector (Promega, Madison, WI, USA) and transformed in Escherichia coli DH5 $\alpha$ cells. Plasmids containing inserts with expected sizes were selected and sequenced with SP6/T7 primers (Table 2) by LGC Genomics (Berlin, Germany). Sequences were submitted to the EMBL Nucleotide Sequence Database.

\section{Phylogenetic analysis of the Rickettsia endosymbionts}

DNA sequences of the amplified Rickettsia species were aligned with Rickettsia sequences found via BLASTNsearches against the NCBI nucleotide (nr) databank [37]. Alignments were made with ClustalW as implemented in BioEdit [38]. A concatenated alignment of three genes was constructed, using the $16 S$ rRNA gene, the citrate synthase gene (gltA) and the cytochrome c oxidase I gene ( $\operatorname{coxA})$. Genes used for constructing the phylogenetic tree are summarized in additional file 1. Missing data was allowed in our alignment, as not all three genes have been sequenced for all used Rickettsia sequences [18]. Phylogenetic reconstruction was performed under Bayesian Maximum Likelihood Inference, using Mr. Bayes version 3.1.2 [39]. The model of evolution was chosen with MrModeltest version 2.2 [40] and the Akaike information criterion. The general time reversible (GTR) + invariant sites (I) + gamma distribution $(\mathrm{G})$ model was chosen, in which $10^{6}$ generations were analyzed, sampling trees every 100 generations. The first 2500 trees were discarded as 'burn-in'. Orientia tsutsugamushi was chosen as the outgroup. All trees were visualized in Treeview [41].

\section{Denaturing Gradient Gel Electrophoresis (PCR-DGGE)}

A PCR-DGGE was performed using the hypervariable V3-region of the $16 S$ rRNA gene. For this purpose, genomic DNA was extracted from male and female adults from the collected $M$. pygmaeus and M. caliginosus populations and from a tetracycline-cured strain of M. pygmaeus. Five to ten adults were pooled for each population. First, a PCR-DGGE was carried out using a non-nested PCR approach with primer pair 318F-518R (Table 2) in $50 \mu$ l reaction mixtures as described above. Amplification conditions were: $95{ }^{\circ} \mathrm{C}$ for $5 \mathrm{~min}$, followed by 33 cycles of $95{ }^{\circ} \mathrm{C}$ for $30 \mathrm{~s}, 55^{\circ} \mathrm{C}$ for $45 \mathrm{~s}, 72{ }^{\circ} \mathrm{C}$ for 1 min $30 \mathrm{~s}$ and a final elongation of $65 \mathrm{~min}$ at $72{ }^{\circ} \mathrm{C}$ to avoid artifactual double bands [42]. However, this approach also amplified the $18 S$ rRNA gene of Macrolophus spp. (data not shown). The high amplification of this gene can suppress the detection of bacteria with a low titer. Consequently, a semi-nested PCR was carried out on all populations to avoid the Macrolophus $18 \mathrm{~S}$ rDNA band showing up in the PCR-DGGE-profile. The semi-nested PCR was carried out using the 27F-primer, which is widely used for the molecular detection of bacteria $[43,44]$. The first PCR-step was performed using the primer pair $27 \mathrm{~F}-518 \mathrm{R}$ with amplification conditions: $5 \mathrm{~min}$ at $95^{\circ} \mathrm{C}, 13$ cycles of $30 \mathrm{~s}$ at $95{ }^{\circ} \mathrm{C}, 45 \mathrm{~s}$ at $55^{\circ} \mathrm{C}$, $1 \mathrm{~min} 30 \mathrm{~s}$ at $72{ }^{\circ} \mathrm{C}$ and a final elongation of $65 \mathrm{~min}$ at $72{ }^{\circ} \mathrm{C}$. Next, $1 \mu \mathrm{l}$ of each product was used in a touchdown PCR reaction with primers $338 \mathrm{f}-518 \mathrm{R}$ with a profile of $5 \mathrm{~min}$ at $95^{\circ} \mathrm{C}, 10$ cycles of $30 \mathrm{~s}$ at $95{ }^{\circ} \mathrm{C}, 45 \mathrm{~s}$ at $\left(60{ }^{\circ} \mathrm{C}-0.5{ }^{\circ} \mathrm{C}\right), 1 \mathrm{~min} 30 \mathrm{~s}$ at $72{ }^{\circ} \mathrm{C}, 13$ cycles of $30 \mathrm{~s}$ at $95{ }^{\circ} \mathrm{C}, 45 \mathrm{~s}$ at $55^{\circ} \mathrm{C}, 1 \mathrm{~min} 30 \mathrm{~s}$ at $72{ }^{\circ} \mathrm{C}$ and a final elongation step of $65 \mathrm{~min}$ at $72{ }^{\circ} \mathrm{C}$. This PCR-DGGE provided a similar profile as the non-nested PCRDGGE, but the eukaryotic $18 S$ rRNA gene was absent. The empty lane of the no-template control indicated the absence of contamination. The Bio-Rad DCode system was used for the analysis. Gels with $8 \%(w / v)$ polyacrylamide were ran in 1 x TAE (40 mM Tris-Cl, $20 \mathrm{mM}$ glacial acetic acid, $1 \mathrm{mM}$ disodium EDTA. $2 \mathrm{H}_{2} \mathrm{O}, \mathrm{pH}$ 7.4) with a denaturing gradient of 45 to $60 \%$ (100\% denaturant contains $7 \mathrm{M}$ urea and $40 \%$ formamide) for $16 \mathrm{~h}$ at $38 \mathrm{~V}$. Gels were stained with SYBR-Green and visualized under UV light (Isogen ProXima 16 Phi system, Isogen Life Science, Sint-Pieters-Leeuw, Belgium). 
To analyze the different bands of the DGGE-pattern, bands were excised from gel, and washed for three times in sterile water. DNA was then eluted from the gel by heating at $37{ }^{\circ} \mathrm{C}$ with $100 \mu \mathrm{l}$ of sterile water; $1 \mu \mathrm{l}$ was used for reamplification. PCR-products were cloned in the pGEM-T vector, reamplified using primer pair 338F-518R and run on a PCR-DGGE gel to discriminate the different bands. Plasmids corresponding to bands of interest were sent to LGC genomics for sequencing.

\section{Fluorescence in situ hybridisation}

The co-localization of Rickettsia and Wolbachia in the reproductive tissues was confirmed with a fluorescent in situ hybridization (FISH). The analysis was carried out following the protocol of Crotti et al. [45] for wholemounted samples with slight modifications. Ovaries of infected and cured M. pygmaeus females were collected in a drop of 1 x PBS under a stereomicroscope, fixed for $1 \mathrm{~h}$ in $4 \%$ paraformaldehyde in $1 \mathrm{x}$ PBS and washed three times with $1 \mathrm{x}$ PBS. The ovaries were then incubated for $1 \mathrm{~min}$ in a $100 \mu \mathrm{g} / \mathrm{ml}$ pepsin solution and washed again three times with $1 \mathrm{x}$ PBS and one time with the hybridization buffer without probe $(2 \times$ SSC, 50 $\%$ formamide). Hybridization was carried out overnight at $46^{\circ} \mathrm{C}$ in hybridization buffer with $10 \mathrm{pmol} / \mathrm{ml}$ fluorescent probe. The next day, samples were washed in hybridization buffer without probe, two times in $0.1 \mathrm{x}$ SSC and two times in $1 \mathrm{x}$ PBS. Subsequently, the samples were whole-mounted with Vectashield Mounting Medium (Vector Labs, Burlingame, CA, USA) and images were acquired using a Nikon A1R confocal microscope, mounted on a Nikon Ti body, using a $60 \mathrm{x}$ (NA1.4) oil objective. Probes used for the analysis were the Rickettsia-specific probe Rb1-Cy3 [33] (5'-Cy3TCCACGTCGCCGTCTTGC-3'), and both WOL2 [46] (5'-Cy5-CTTCTGTGAGTACCGTCATTATC-3') and WOL3 [47] (5'-Cy5-AACCGACCCTATCCCTTCGAATA-3'), targeting Wolbachia. A no-probe experiment and the hybridization of an aposymbiotic ovariole was executed as a specifity control.

\section{Fitness effects}

To investigate the effect of the endosymbionts on the fitness of $M$. pygmaeus, nymphal development and fecundity of the predator were compared between the infected laboratory-strain of $M$. pygmaeus and an endosymbiontfree $M$. pygmaeus population. The general procedure largely follows the method of Vandekerkhove et al. [48], with slight modifications. First instars $(<24 \mathrm{~h})$ of the $39^{\text {th }}$ generation of each population were individually caged in vented plastic cups ( $4 \mathrm{~cm}$ diameter and $2.5 \mathrm{~cm}$ high) containing a wax paper drenched in paraffin. A parafilm dome filled with water and E. kuehniella eggs were provided as a source of water and food, respectively. Water domes and eggs were replaced every two days. Nymphs which died on the first or second day of the experiment were replaced by new ones, assuming that their death was caused by handling. Nymphal development and survival were checked daily. Nymphs that successfully reached the adult stage were sexed and weighed at emergence (i.e., within $24 \mathrm{~h}$ after moulting). Adult pairs were then transferred to a new plastic cup containing a tobacco leaf disc placed with the upper side on a $1 \%$ agar layer. Two crosses were tested: infected males with infected females [I $\sigma^{*} \times$ IO] and uninfected males with uninfected females [U $\sigma^{*} \mathrm{x}$ UO]. Eggs of E. kuehniella were offered as a food source for the adult predators, whereas the tobacco leaf served as a source of moisture and an oviposition substrate. After 7 days, females were dissected and oocytes were counted [28]: late vitellogenic to mature oocytes were scored 1; early to mid vitellogenic oocytes 0.5 and previtellogenic oocytes 0.25 . Mature oocytes present in the oviducts were also scored as 1 . The scores for all ovarioles were then summed providing a weighted sum of oocytes, which can reliably be used to predict the lifetime fecundity of $M$. pygmaeus [28]. Furthermore, the leaf discs were immersed in safranin and screened for oviposited eggs. Effects of infection status on nymphal development, adult weight and fecundity were statistically examined by a one-way analysis of variance (ANOVA) or a Mann-Whitney U Test using SPSS 17.0 [49].

\section{Results}

\section{Insect species collection and identification}

The Macrolophus populations from Greece and Italy were collected on the wild plants Solanum nigrum and Dittrichia viscosa which are considered to be conservation host plants for $M$. pygmaeus and M. caliginosus, respectively $[50,51]$. Some $M$. pygmaeus populations were also collected on $D$. viscosa, although their survival is reported to be poor on this plant [50]. In Spain, $M$. pygmaeus was also collected on tomato, Solanum lycopersicum.

The primer pairs CB1-CB2 and LAU1f-CB2, which both amplify a part of the cytochrome $b$ gene, were used to elucidate the species identity of the collected insects. In accordance with Martinez-Cascales et al. [35], the primer pair CB1-CB2 yielded poor results for $M$. caliginosus DNA; therefore the LAU1F-CB2 primer pair was used for species identification. The latter amplified all Macrolophus-DNA, although the LAU1-primer was designed to specifically amplify $M$. caliginosus-DNA [35]. Results are summarized in Table 1.

\section{S rRNA gene sequencing}

A PCR assay was carried out on a pool of adult $M$. pygmaeus males and females of the laboratory strain using 
general primers targeting the bacterial $16 S \mathrm{rRNA}$ gene. A total of 23 clones were sequenced, varying in length depending on the use of primer pair $27 \mathrm{~F}-806 \mathrm{R}$ or $27 \mathrm{~F}$ 1525R (Table 2). These sequences were compared with the non-redundant (nr) nucleotide database at the National Center for Biotechnology (NCBI) using BLASTN. Three of the cloned bacteria can be considered as endosymbionts, namely Wolbachia and two Rickettsia species (Table 3). The two Rickettsia species were identified using the primer pair 27F-806R. In order to obtain approximately 1500 base pairs of their $16 S$ rRNA gene, a PCR using a forward primer based on the partially known sequences of the two Rickettsia species was designed and combined with the general bacterial 1492R primer (Rick1F-1492R, Table 2). One of these Rickettsia species exhibited a 99\% similarity to Rickettsia limoniae and the Rickettsia endosymbiont of the water beetle Deronectes platynotus. The second one was $99 \%$ similar to Rickettsia bellii and the Rickettsia endosymbiont of the pea aphid Acyrthosiphon pisum. Other cloned bacteria are not regarded as endosymbiotic bacteria, but rather as environmental or gut bacteria (Table 3).

To investigate the presence of similar endosymbionts in the other (wild) populations of $M$. pygmaeus and the closely related species $M$. caliginosus, a PCR assay was performed using Rickettsia- (RicklimF-1492R and 27F-
RickBelR) and Wolbachia-specific primers (Table 2). This assay revealed the presence of all three endosymbionts in all M. pygmaeus populations. In addition, Wolbachia and a Rickettsia-species that was $100 \%$ similar to the $R$. limoniae-species of $M$. pygmaeus were detected in all $M$. caliginosus populations. However, the bellii-like Rickettsia present in $M$. pygmaeus was not found in $M$. caliginosus.

A diagnostic PCR using Rickettsia-specific primers and $w s p$-primers on 20 adult males and 20 adult females of the laboratory strain of $M$. pygmaeus showed that all tested individuals were infected with the three endosymbionts. The same experiment was repeated using a $M$. caliginosus strain found on D. viscosa in Sardinia, Italy, revealing that all adults were infected with Wolbachia and $R$. limoniae. The presence of Wolbachia and Rickettsia in the ovaries of M. pygmaeus and M. caliginosus was confirmed by PCR using 20 ovaries of both species.

\section{Phylogenetic analysis}

A Bayesian inference (BI) phylogenetic tree based on a concatenated alignment of the $16 S$ rRNA, gltA and coxA genes was constructed to check the phylogeny of the two Rickettsia species (Fig. 1). However, the gltA-primers did not amplify the citrate synthase gene of 'Macrolophus symbiont 2' (Fig. 1).The phylogenetic relationships of the Wolbachia strain in M. pygmaeus were

Table 3 Partial 16S rDNA sequences isolated in this study by cloning and PCR-DGGE. The accession number of the closest relative is indicated between brackets.

\begin{tabular}{|c|c|c|c|c|}
\hline Closest known relative & Phylogenetically related class & Sequenced length (bp) & Identity (\%) & Accession no. \\
\hline \multicolumn{5}{|l|}{$16 S$ rRNA PCR cloning of $M$. pygmaeus } \\
\hline Rickettsia limoniae strain Brugge (AF322443) & Alpha-proteobacteria & 1422 & 99 & HE583202 \\
\hline Wolbachia endosymbiont of Culex quinquefasciatus (AM999887) & Alpha-proteobacteria & 1461 & 98 & HE583204 \\
\hline Uncultured bacterium (GQ360069) & Gamma-proteobacteria & 1496 & 99 & HE583205 \\
\hline Uncultured bacterium (HM812162) & Firmicutes & 767 & 100 & HE583206 \\
\hline Uncultured bacterium (FJ512272) & Firmicutes & 764 & 99 & HE583207 \\
\hline Uncultured bacterium (GU118480) & Beta-proteobacteria & 743 & 99 & HE583208 \\
\hline \multicolumn{5}{|l|}{ PCR-DGGE* } \\
\hline 1) Wolbachia endosymbiont of Polydrusus pilifer (JF304463) & Alpha-proteobacteria & 135 & 100 & HE583209 \\
\hline 2) Rickettsia bellii (L36103) & Alpha-proteobacteria & 135 & 99 & HE583210 \\
\hline 3) Uncultured bacterium (JF011887) & Gamma-proteobacteria & 160 & 100 & HE583211 \\
\hline 5) Rickettsia limoniae strain Brugge (AF322443) & Alpha-proteobacteria & 137 & 100 & HE583213 \\
\hline 6) Uncultured Streptococcus sp. (GU132113) & Firmicutes & 161 & 100 & HE583214 \\
\hline 7) Uncultured bacterium (FN421660) & Gamma-proteobacteria & 157 & 99 & HE583215 \\
\hline 8) Rickettsia bellii (L36103) & Alpha-proteobacteria & 135 & 99 & HE583216 \\
\hline 9) Uncultured bacterium (JF206698) & Gamma-proteobacteria & 160 & 100 & HE583217 \\
\hline 10) Serratia sp. (HQ891979) & Gamma-proteobacteria & 160 & 100 & HE583218 \\
\hline 11) Enterobacter cloacae (HQ888762) & Gamma-proteobacteria & 160 & 100 & HE583219 \\
\hline 12) Serratia sp. (HQ888762) & Gamma-proteobacteria & 160 & 100 & HE583220 \\
\hline
\end{tabular}

*the numbers correspond to the bands in Fig. 2 and Fig. 3 


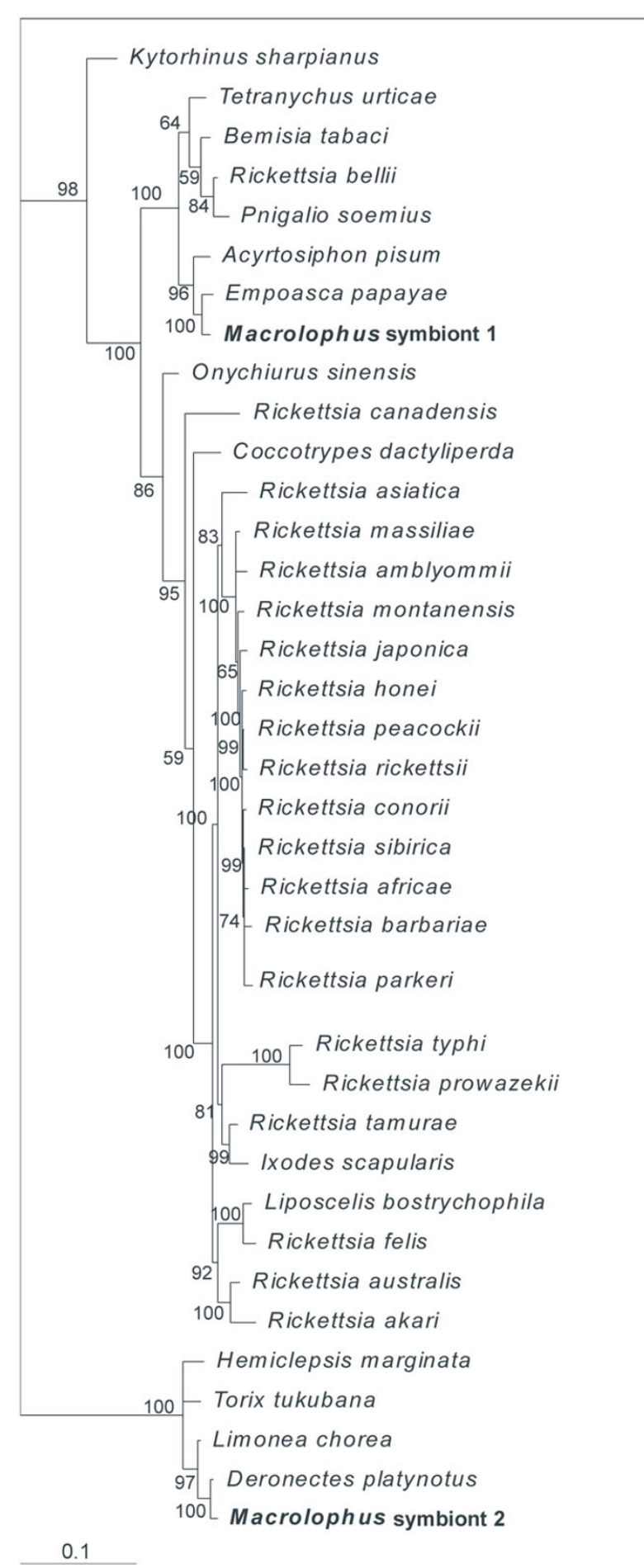

\section{Bellii group}

\section{Spotted fever group}

\section{Typhus group}

\section{Transitional group}

Limoniae group

Figure 1 Phylogenetic tree of Rickettsia. Rooted phylogenetic tree estimated using Bayesian inference of phylogeny, based on concatenated sequences of 16S, gltA and coxA of Rickettsia. Posterior probabilities supporting nodes (> 50) are shown. The different Rickettsia-strains are indicated either as their species name or as their host species. Group names are indicated on the right. 
previously elucidated [29]. The two Rickettsia species are related to two different clades. The phylogenetic tree indicated that the first M. pygmaeus Rickettsia endosymbiont is associated with the 'Bellii' group, clustering with the Rickettsia endosymbionts of the two-spotted spider mite Tetranychus urticae, the pea aphid A. pisum and the tobacco whitefly Bemisia tabaci, among others. The second Rickettsia endosymbiont is situated in the ancestral 'Limoniae' group, clustering with the Rickettsia endosymbiont of the water beetle Deronectes platynotus and the cranefly Limonia chorea.

\section{Denaturing Gradient Gel Electrophoresis (PCR-DGGE)}

PCR-DGGE-profiling targeting the hypervariable V3region of the $16 S$ rRNA gene (Table 2) was applied to analyze the microbial community of the studied $M$. pygmaeus and $M$. caliginosus populations. These populations exhibited similar profiles (Fig. 2), as both species had bands with high and low intensity.

These bands were excised from gel, eluted and cloned. After sequencing, BLASTN searches were performed against the nr-database of NCBI. Table 3 summarizes the BLAST-results of the sequenced bands. In corroboration of the cloning experiments using the $16 \mathrm{~S}$ rRNA gene, bands with a high similarity to Wolbachia, $R$. bellii and $R$. limoniae were found in the M. pygmaeus populations, while the PCR-DGGE-profile of $M$. caliginosus lacked the band attributed to the bellii-like Rickettsia. The other excised bands corresponded to bacteria from the Gamma-proteobacteria and Firmicutes. These bacteria are generally considered as environmental bacteria or micro-organisms related to the digestive tract [23], but their function is unknown in
Macrolophus spp. The profile of the cured strain only showed the $18 S$ rRNA band in the non-nested DGGEPCR (data not shown), and no bands in the nested DGGE-PCR (Fig. 3). One band, corresponding to an uncultured Gamma-proteobacterium, was found in five Macrolophus populations.

Furthermore, a PCR-DGGE-profile of the ovaries and the gut of the laboratory strain of $M$. pygmaeus and $M$. caliginosus was generated (Fig. 3). DNA was extracted from a pool of 20-30 dissected ovaries and 20-30 dissected guts, respectively. The PCR-DGGE-profile of the ovaries of $M$. pygmaeus and $M$. caliginosus only showed the bands related to Wolbachia and the Rickettsia species. The DGGE-profile of the guts showed the presence of the two Rickettsia species and the Gamma-proteobacteria, but the band corresponding to Wolbachia was very faint.

\section{FISH}

Vertical transmission of the Wolbachia and Rickettsia endosymbionts was confirmed by FISH analysis on the ovaries of the laboratory strain of $M$. pygmaeus. A high concentration of both Wolbachia and Rickettsia was observed inside the ovarioles (Fig. 4 A-B), while no infection was detected in a cured ovariole (Fig. 4 C). A 3D-view of a $10 \mu \mathrm{m}$ cross-section made by a stack of 21 confocal slices provided a clear distinction of single Rickettsia and Wolbachia bacteria inside the ovarioles (Fig. 5). A noprobe control verified the specific fluorescence of the endosymbionts, as no fluorescence was observed.

\section{Fitness effects}

Bio-assays were carried out to examine potential fitness effects of the endosymbionts on their Macrolophus host.

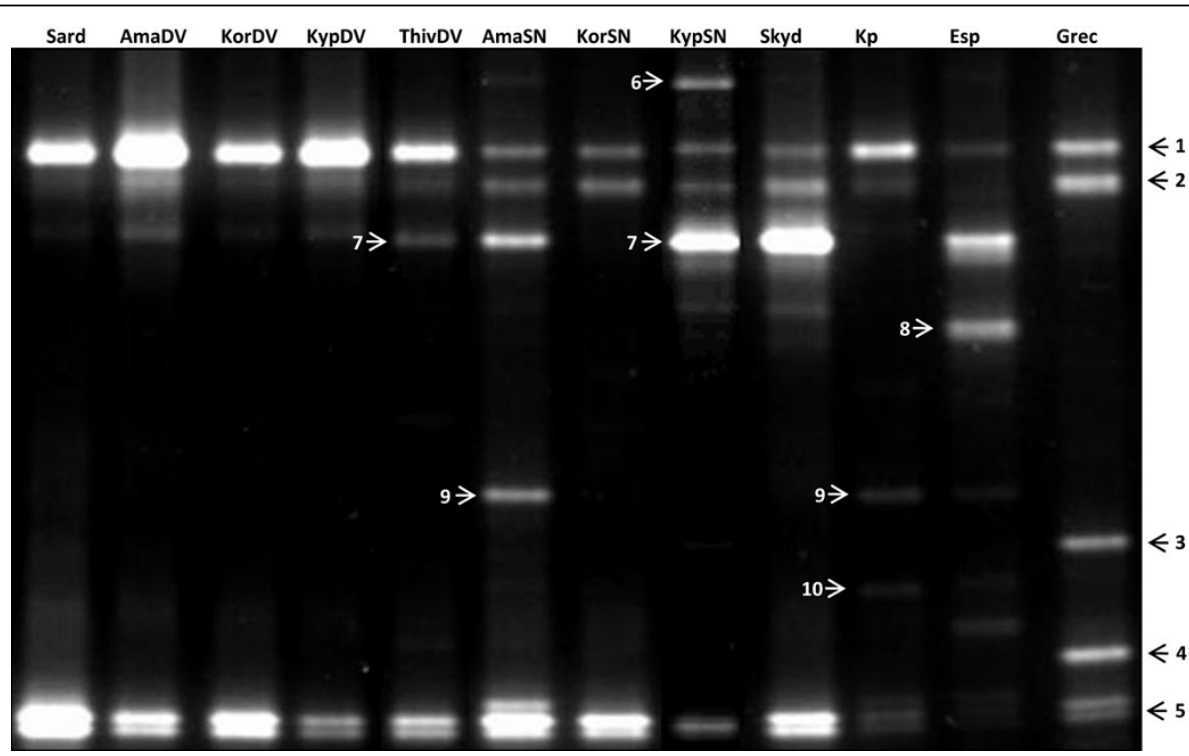

Figure 2 PCR-DGGE profiles of hypervariable 16 rRNA V3-regions of various $M$. pygmaeus and $M$. caliginosus populations. Numbers correspond to PCR-DGGE amplicons that were excised from the gel, cloned and sequenced (Table 3). 


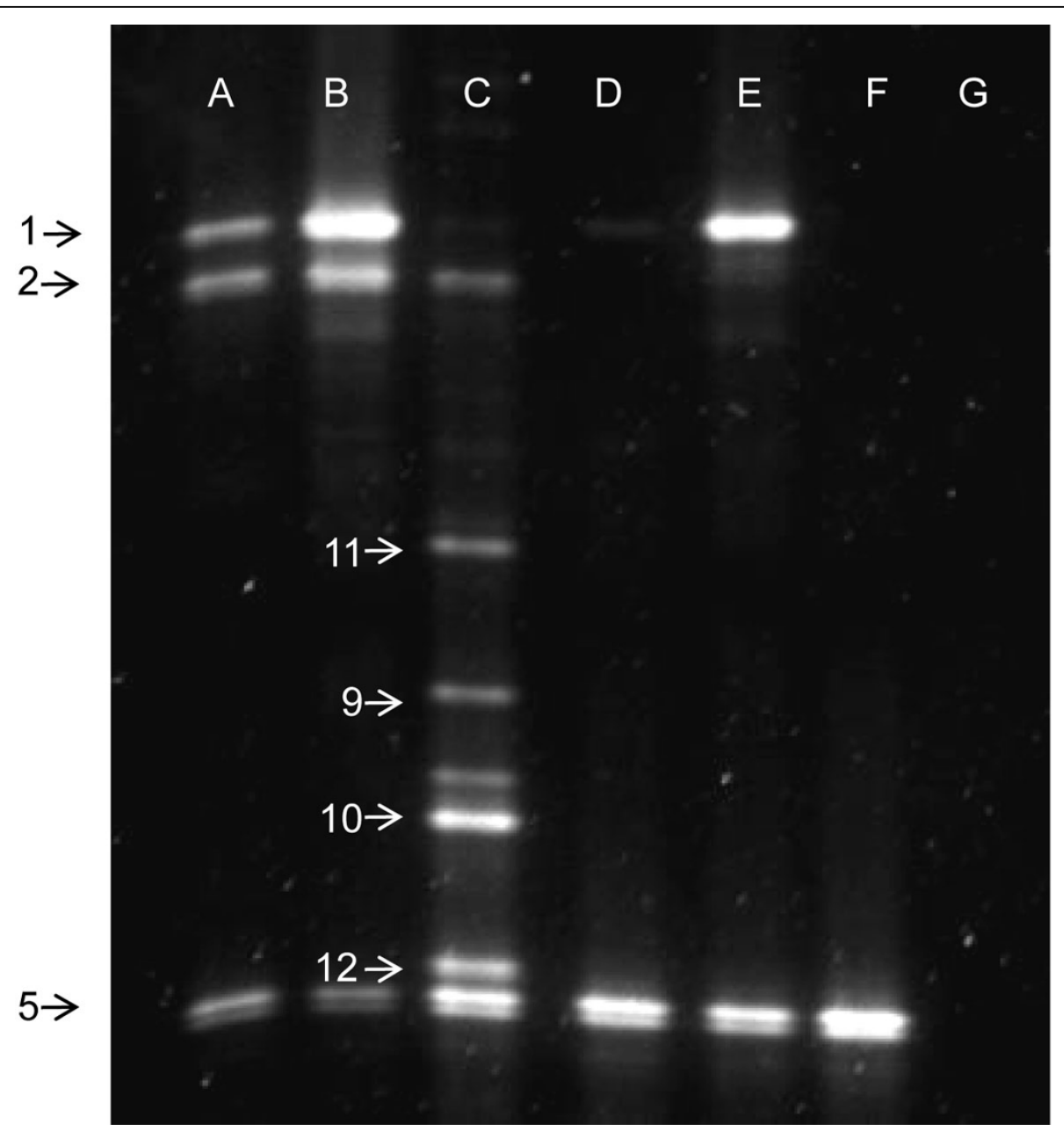

Figure 3 PCR-DGGE on tissues of $\boldsymbol{M}$. pygmaeus and $\boldsymbol{M}$. caliginosus. PCR-DGGE profiles of hypervariable 16 rRNA V3-regions of adults, ovaries and guts of the laboratory strains of $M$. pygmaeus and M. caliginosus. A: M. pygmaeus adults, B: M. pygmaeus ovaries, C: M. pygmaeus guts, D: M. caliginosus adults, E: M. caliginosus ovaries, F: M. caliginosus guts, G: cured M. pygmaeus adults. Numbers correspond to PCR-DGGE amplicons that were excised from the gel, cloned and sequenced (Table 3).

In a first experiment, nymphal development was compared between infected and uninfected individuals of $M$. pygmaeus, revealing positive effects of the infection on some developmental traits (Table 4). Infected M. pygmaeus males developed significantly faster than cured males $(P<0.001)$. Moreover, infected females were significantly heavier at emergence than uninfected ones $(\mathrm{P}=0.011)$. In a second experiment, fecundity was compared between infected and uninfected $M$. pygmaeus females. Infection status had no effect on the amount of eggs laid $(\mathrm{P}=0.575)$, nor on the oocyte counts of dissected females $(\mathrm{P}=0.069)$.

\section{Discussion}

In the present study, the microbial community of various populations of two predators of the mirid genus Macrolophus was investigated. The bacterial diversity of
Macrolophus spp. was explored by cloning 16S rRNA sequences and PCR-DGGE. The cloning experiment was executed on the laboratory strain of $M$. pygmaeus, revealing the presence of bacteria from the Alpha-proteobacteria, Beta-proteobacteria, Gamma-proteobacteria and Firmicutes classes (Table 3). Three bacteria $-R$. limoniae, $R$. bellii and Wolbachia- can be considered as endosymbionts. The presence of these endosymbionts was confirmed using a PCR-DGGE profile of the hypervariable V3 region of the $16 S$ rRNA gene. The PCRDGGE was carried out using a semi-nested approach, as the bacterial primers targeting the V3-region are known to amplify eukaryotic DNA [52]. Three bands corresponding to these three endosymbionts recurred in all studied M. pygmaeus populations. The DGGE-profile of bacteria in the $M$. caliginosus populations were similar to those of $M$. pygmaeus, confirming the presence of 


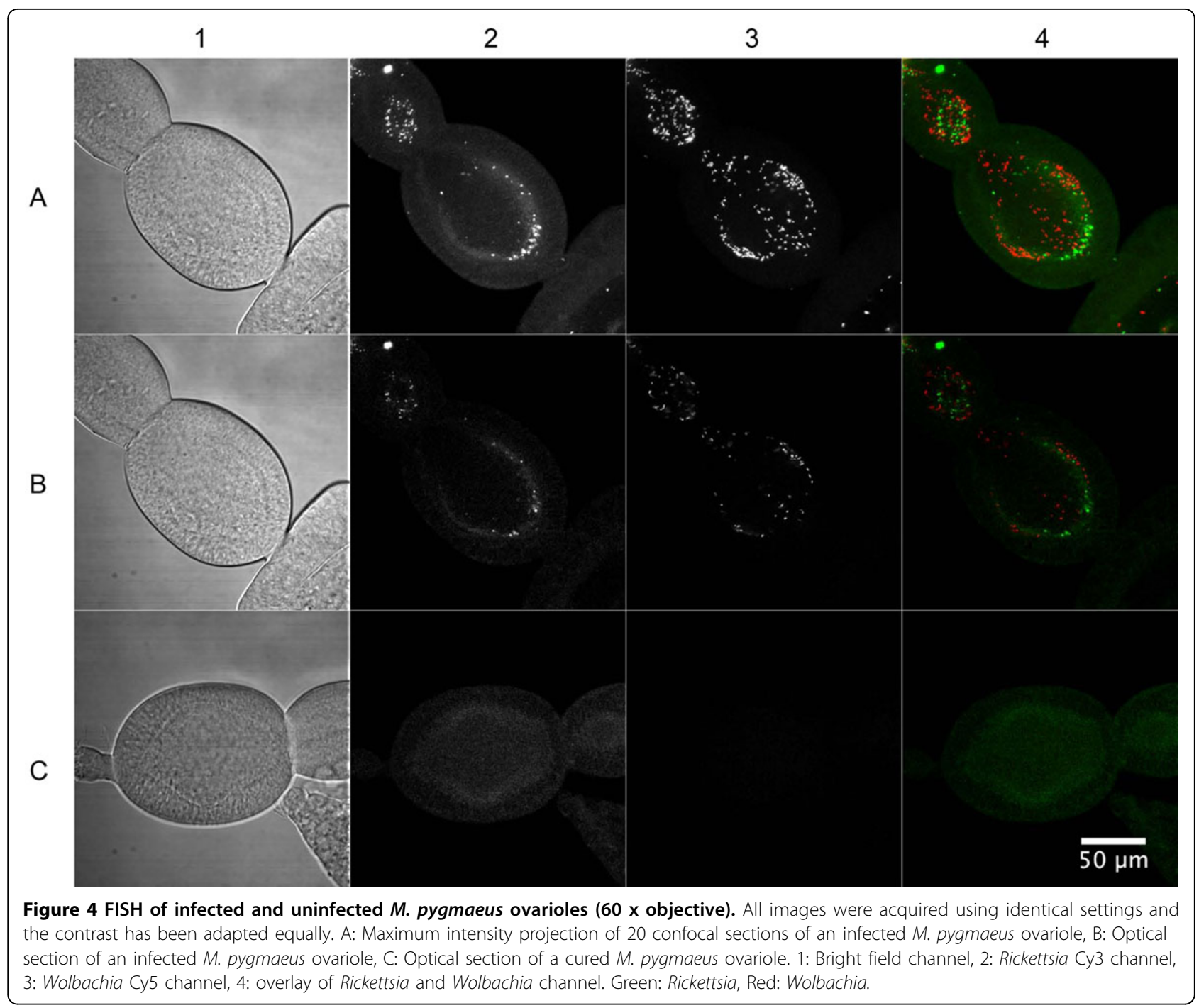

Wolbachia and the Rickettsia strain from the 'Limoniae' group, but the bellii-like Rickettsia was not found (Fig. 2). A PCR using specific primers for each endosymbiont confirmed this result.

The bands with lower density present in some populations corresponded to the Gamma-proteobacteria and Firmicutes. Most of these bands were attributed to Serratia species of the Enterobacteriaceae family, which have been found in the gut of various insect orders, including Hymenoptera, Lepidoptera, Neuroptera and Hemiptera [53-56]. One band however (Fig. 2, no. 7), has been amplified in five wild Macrolophus populations. This band corresponded to an uncultured Gamma-proteobacterium, the role of which is unknown. The low bacterial diversity in the gut of $M$. pygmaeus may be attributed to its natural diet. A more diverse bacterial community is mostly detected in insects that consume nutritionally poor diets [57], whereas the main food of Macrolophus bugs consists of nutrient-rich arthropod prey. Also, the microbial diversity of the investigated Macrolophus spp. may have been underestimated by the dominance of the endosymbionts in its host. Samples of the wild Macrolophus populations were collected in ethanol and DNA-extraction was performed on whole adults; gut dissections were thus only feasible for the two laboratory reared populations. The faint bands in the DGGEprofile of the wild populations of Macrolophus may originate from prey remnants in the gut. A PCRDGGE profile of the gut of the laboratory populations of $M$. pymaeus and M. caliginosus established the presence of the Gamma-proteobacteria and the Rickettsia endosymbionts in M. pygmaeus (Fig. 3), whereas the gut of M. caliginosus was only infected by $R$. limoniae. In both species, Wolbachia was virtually absent in the gastro-intestinal tract. 


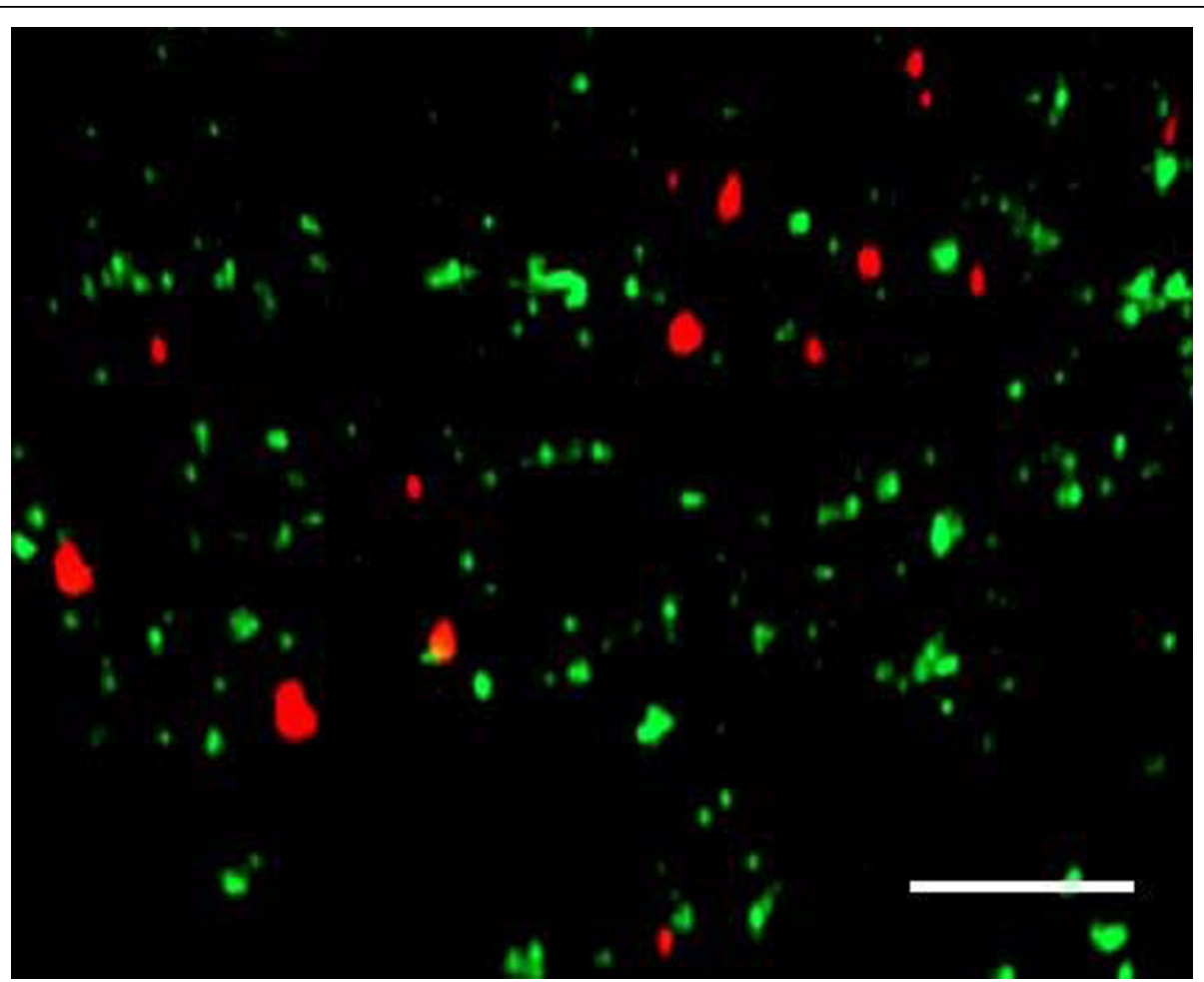

Figure 5 Volume rendered view of an infected ovariole, showing the colocalization of Rickettsia (green) and Wolbachia (red). The picture was made in NIS-viewer (Nikon Instruments Inc., Badhoevedorp. The Netherlands) based on 21 confocal slices. Scale bar = 10 $\mu \mathrm{m}$.

The DGGE profile of the ovaries only indicated an infection by the Wolbachia and Rickettsia endosymbionts, suggesting that no other bacteria infected the reproductive tissues. A diagnostic PCR on adults and ovaries of $M$. pygmaeus and M. caliginosus confirmed that all individuals are multiple infected and that the endosymbionts are vertically transmitted, implying that the infections are fixed. A FISH analysis confirmed high densities of both Wolbachia and Rickettsia in the ovarioles of M. pygmaeus (Fig. 4 and 5), suggesting a high rate of vertical transmission to the progeny [58].

Wolbachia is the only endosymbiont infecting the studied Macrolophus spp. which is known to cause CI in its insect host [7]. As there is no evidence in the literature that Rickettsia is involved in causing CI effects in insects, the strong CI observed in M. pygmaeus [24] is more likely related to the presence of Wolbachia rather than the Rickettsia species. The impact of the Rickettsia species on the biology of Macrolophus bugs is as yet unclear. A bio-assay was performed to examine differences in development and fecundity between an endosymbiont-infected and a cured population of $M$. pygmaeus. In accordance with the findings of Chiel el al. [59] on the tobacco whitefly B. tabaci, nymphal development of infected individuals was faster (albeit in the current study only for males), but fecundity was not affected. On the other hand, Himler et al. [60] demonstrated the rapid spread and fixation of a southwest American whitefly population infected with Rickettsia bellii. This population dominated all other populations by large fitness advantages and a higher proportion of females. Although the proportion of females was also

Table 4 Nymphal developmental time, adult weight, sex ratio, number of eggs laid in the first week and oocyte counts of infected and uninfected $M$. pygmaeus.

\begin{tabular}{|c|c|c|c|c|c|c|c|}
\hline \multirow[t]{2}{*}{ Cross } & \multicolumn{2}{|c|}{ Developmental time (days) } & \multicolumn{2}{|c|}{ Adult weight (mg) } & \multirow{2}{*}{$\begin{array}{l}\text { Sex ratio }\left(0^{n}:\right. \\
\text { O) }\end{array}$} & \multirow[t]{2}{*}{ No. of eggs laid } & \multirow{2}{*}{$\begin{array}{l}\text { Weighted sum of } \\
\text { oocytes }\end{array}$} \\
\hline & Males (n) & Females (n) & Males (n) & Females (n) & & & \\
\hline $1 \sigma^{\prime} \times 1 Q$ & $\begin{array}{l}17.61 \pm 0.13 a \\
(28)\end{array}$ & $\begin{array}{l}18.04 \pm 0.20 a \\
(23)\end{array}$ & $\begin{array}{l}0.82 \pm 0.02 \mathrm{a} \\
(28)\end{array}$ & $\begin{array}{l}1.31 \pm 0.02 \mathrm{a} \\
(23)\end{array}$ & $1: 0.8$ & $\begin{array}{l}12.33 \pm 1.60 a \\
(30)\end{array}$ & $15.02 \pm 0.97$ a (30) \\
\hline $\begin{array}{l}\text { Uor x } \\
\text { UO }\end{array}$ & $\begin{array}{l}18.54 \pm 0,19 b \\
(26)\end{array}$ & $\begin{array}{l}18.60 \pm 0.30 a \\
(15)\end{array}$ & $\begin{array}{l}0.83 \pm 0.02 \mathrm{a} \\
(26)\end{array}$ & $\begin{array}{l}1.19 \pm 0.04 b \\
(15)\end{array}$ & $1: 0.6$ & $\begin{array}{l}10.96 \pm 1.20 \mathrm{a} \\
(22)\end{array}$ & $12.44 \pm 0.94$ a (28) \\
\hline
\end{tabular}

Mean values $( \pm$ SE) within a column followed by the same letter are not significantly different $(P>0.05$, One-Way ANOVA or Mann-Whitney $U$ test) 
higher in the infected M. pygmaeus population in our study (Table 4), the observed effects do not allow to explain the Rickettsia fixation in Macrolophus.. The Rickettsia symbiont of the booklouse $L$. bostrychophila is essential for the development of the embryos [24]. Conversely, cured $M$. pygmaeus adults produce normal progeny, confirming the facultative secondary character of Rickettsia in this host. Theoretically, the Rickettsia endosymbionts could have invaded its Macrolophus host by 'hitchhiking' with the CI-inducing Wolbachia endosymbiont, as CI promotes females with multiple infections [61].

Besides influencing developmental and reproductive parameters, microbial endosymbionts can affect their host in various other ways, e.g. by being nutritional mutualists. Recently, Wolbachia has been shown to provide a positive fitness effect in iron-restricted diets [62]. Also, the so-called 'symbiont-mediated protection' is an emerging topic [2,3,59]: here, insects are protected against pathogens (including viruses [51,63] and fungi [64]) or parasitoids (e.g. the braconid wasp Aphidius in aphids [65]) by vertically transmitted symbionts (reviewed in [3]). This protection could be a potential system for endosymbionts to preserve their infection.

To clarify the impact of the individual endosymbiont species, their hosts can be partially cured, yielding singly infected individuals. White et al. [66] used low dose antibiotics to partially cure the doubly infected parasitoid wasp Encarsia inaron. This wasp needed to be cured of Wolbachia and Cardinium, two endosymbionts belonging to two different classes, the Alpha-proteobacteria and Bacteroidetes respectively. However, Rickettsia and Wolbachia belong to the same family (Rickettsiaceae), which would complicate partial curing in Macrolophus. The role of Wolbachia and Rickettsia in M. caliginosus has not been demonstrated. Establishing an endosymbiont-free population and performing crossing experiments can be a first step to investigate possible reproductive effects also in the latter Macrolophus species.

A Rickettsia-specific phylogenetic tree elucidated that one M. pygmaeus Rickettsia endosymbiont belonged to the 'Limoniae' group, whereas the other is a member of the 'Bellii' group (Fig. 1). The M. pygmaeus Rickettsia endosymbiont belonging to the 'Bellii' group was phylogenetically closely related to the symbionts of natural prey species of the mirid predator, including the twospotted spider mite $T$. urticae, the pea aphid $A$. pisum and the tobacco whitefly B. tabaci. This finding may indicate a possible horizontal transfer between predator and prey. The horizontal transfer of an endosymbiont has, however, currently only been established in an arthropod parasitoid-host system. Chiel et al. [67] investigated the interspecies horizontal transfer of Rickettsia from B. tabaci (belonging to the 'Bellii' group) to its aphelinid parasitoids Eretmocerus emericus and E. emiratus. This Rickettsia infection reached the reproductive tissues of its host, but was not transmitted to its progeny.

Sharing the same habitat and using the same plant tissues may also constitute a transmission route for bacterial endosymbionts. Macrolophus spp. are facultatively phytophagous predators with piercing-sucking mouthparts and may inoculate plant tissues with micro-organisms. Other species, feeding on the same host plant may then take up these micro-organisms. Furthermore, the PCR-DGGE profile showed the presence of $R$. limoniae and $R$. bellii in the gut, suggesting that an infection of the faeces is likely. However, more research is needed to confirm these hypothetical horizontal transmission routes.

\section{Conclusions}

In this study, the microbial community of the mirid predators M. pygmaeus and M. caliginosus was explored by $16 S$ rRNA gene cloning and PCR-DGGE. Both species were infected with Wolbachia and a Rickettsia species related to $R$. limoniae. Furthermore, M. pygmaeus was infected with a Rickettsia species belonging to the 'Bellii' group. The latter is phylogenetically related to Rickettsia species in their arthropod prey, including B. tabaci and T. urticae, which may be indicative of a potential horizontal transmission in a predator-prey system. All endosymbionts were vertically transmitted to their progeny, as demonstrated by a FISH analysis and a diagnostic PCR on the ovaries. A bio-assay with M. pygmaeus indicated that infection with the endosymbionts did not have fitness costs for the predator. Further research is warranted to elucidate the role of Rickettsia in its Macrolophus host.

\section{Additional material}

Additional file 1: Accession numbers phylogenetic tree. Description: Accession numbers of the 16s rRNA, glta and coxA genes of different species used for constructing the phylogenetic tree of Rickettsia.

\section{Acknowledgements}

This work was supported by grant number SB-73469 from the Institute for the Promotion of Innovation through Science and Technology in Flanders (IWT-Vlaanderen). TVL is a postdoctoral fellow of the Research Foundation Flanders (FWO). The financial support of the Hercules Foundation (project AUGE/013) is gratefully acknowledged. We thank Dr. Dionyssios Perdikis for collecting the Greek Macrolophus populations. We acknowledge Tim Lacoere for assistance with the PCR-DGGE's. Thanks also go to Koppert BV, The Netherlands, for providing us with a laboratory strain of M. pygmaeus. This article has been published as part of BMC Microbiology Volume 11 Supplement 1, 2012: Arthropod symbioses: from fundamental studies to pest and disease mangement. The full contents of the supplement are available online at http://www.biomedcentral.com/1471-2180/12?issue=S1. 


\section{Author details}

'Laboratory of Agrozoology, Department of Crop Protection, Faculty of Bioscience Engineering, Ghent University, Ghent, Belgium. ${ }^{2}$ Laboratory of Microbial Ecology and Technology (LabMET), Faculty of Bioscience Engineering, Ghent University, Gent, Belgium. ' 2 Laboratory of Bio-imaging and Cytometry, Department of Molecular Biotechnology, Faculty of Bioscience Engineering, Ghent University, Gent, Belgium. ${ }^{4}$ Center for Nanoand Biophotonics (NB-Photonics), Ghent University, Gent, Belgium. ${ }^{5}$ Instituto Murciano de Investigación y Desarrollo Agrario y Alimentario (IMIDA), Departamento de Biotecnología y Protección de Cultivos, La Alberca, Murcia, Spain. ${ }^{6}$ AGRIS Sardegna - DIRVE, Cagliari, Italy. ${ }^{7}$ Laboratory of Applied Molecular Genetics, Department of Molecular Biotechnology, Faculty of Bioscience Engineering, Ghent University, Ghent, Belgium.

\section{Authors' contributions}

TM performed the experiments and wrote the manuscript. TM, TVL and PDC designed the experiments. TVDW and NB helped with the PCR-DGGE experiments. JAS and MN collected Macrolophus bugs in Spain and Italy, respectively. WDV helped with the FISH experiments. TVL, TVDW, GG and PDC revised the manuscript. All authors read and approved the final manuscript.

\section{Competing interests}

The authors declare that they have no competing interests.

Published: 18 January 2012

\section{References}

1. Douglas AE: Nutritional interactions in insect-microbial symbioses: aphids and their symbiotic bacteria Buchnera. Annu Rev Entomol 1998, 43:17-37.

2. Gross R, Vavre F, Heddi A, Hurst GDD, Zchori-Fein E, Bourtzis K: Immunity and symbiosis. Molecular Microbiology 2009, 73(5):751-759.

3. Brownlie JC, Johnson KN: Symbiont-mediated protection in insect hosts. Trends in Microbiology 2009, 17(8):348-354.

4. Werren JH: Biology of Wolbachia. Annu Rev Entomol 1997, 42:587-609.

5. Werren JH, O'Neill SL: The evolution of heritable symbionts. In Influential Passengers: Inherited Microorganisms and Arthropod Reproduction. New York: Oxford University Press;O'Neill SL, Hoffmann AA, Werren JH 1997:1-41.

6. Hilgenboecker $\mathrm{K}$, Hammerstein $\mathrm{P}$, Schlattmann $\mathrm{P}$, Telschow A, Werren JH: How many species are infected with Wolbachia? A statistical analysis of current data. FEMS Microbiol Lett 2008, 281(2):215-220.

7. Stouthamer R, Breeuwer JAJ, Hurst GDD: Wolbachia pipientis: microbial manipulator of arthropod reproduction. Annu Rev Microbiol 1999, 53:71-102

8. Stevens L, Giordano R, Fialho RF: Male-killing, nematode infections, bacteriophage infection, and virulence of cytoplasmic bacteria in the genus Wolbachia. Annu Rev Ecol Syst 2001, 32:519-545.

9. Stouthamer R, Luck RF, Hamilton WD: Antibiotics cause parthenogenetic Trichogramma (Hymenoptera/Trichogrammatidae) to revert to sex. Proc Natl Acad Sci U S A 1990, 87(7):2424-2427.

10. Rousset F, Bouchon D, Pintureau B, Juchault P, Solignac M: Wolbachia endosymbionts responsible for various alterations of sexuality in arthropods. Proc Biol Sci 1992, 250(1328):91-98.

11. Dedeine F, Vavre F, Fleury F, Loppin B, Hochberg ME, Bouletreau M: Removing symbiotic Wolbachia bacteria specifically inhibits oogenesis in a parasitic wasp. Proc Natl Acad Sci U S A 2001, 98(11):6247-6252.

12. Zchori-Fein E, Perlman SJ: Distribution of the bacterial symbiont Cardinium in arthropods. Mol Ecol 2004, 13(7):2009-2016.

13. Zchori-Fein E, Perlman SJ, Kelly SE, Katzir N, Hunter MS: Characterization of a 'Bacteroidetes' symbiont in Encarsia wasps (Hymenoptera: Aphelinidae): proposal of 'Candidatus Cardinium hertigii'. Int I Syst Evol Microbiol 2004, 54:961-968.

14. Gotoh T, Noda H, Ito S: Cardinium symbionts cause cytoplasmic incompatibility in spider mites. Heredity 2007, 98(1):13-20.

15. Skaljac M, Zanic K, Ban SG, Kontsedalov S, Ghanim M: Co-infection and localization of secondary symbionts in two whitefly species. $B M C$ Microbiol 2010, 10:15

16. Perlman SJ, Hunter MS, Zchori-Fein E: The emerging diversity of Rickettsia. Proc Biol Sci 2006, 273(1598):2097-2106.

17. Davis MJ, Ying Z, Brunner BR, Pantoja A, Ferwerda FH: Rickettsial relative associated with papaya bunchy top disease. Curr Microbiol 1998, 36(2):80-84.
18. Weinert LA, Werren JH, Aebi A, Stone GN, Jiggins FM: Evolution and diversity of Rickettsia bacteria. BMC Biol 2009, 7:15.

19. Werren JH, Hurst GDD, Zhang W, Breeuwer JAJ, Stouthamer R, Majerus MEN: Rickettsial relative associated with male killing in the ladybird beetle (Adalia bipunctata). J Bacteriol 1994, 176(2):388-394.

20. Majerus MEN, Hinrich J, Schulenburg GVD, Zakharov IA: Multiple causes of male-killing in a single sample of the two-spot ladybird, Adalia bipunctata (Coleoptera: Coccinellidae) from Moscow. Heredity 2000, 84(5):605-609.

21. Lawson ET, Mousseau TA, Klaper R, Hunter MD, Werren JH: Rickettsia associated with male-killing in a buprestid beetle. Heredity 2001, 86:497-505.

22. Hagimori T, Abe Y, Date S, Miura K: The first finding of a Rickettsia bacterium associated with parthenogenesis induction among insects. Curr Microbiol 2006, 52(2):97-101.

23. Giorgini M, Bernardo U, Monti MM, Nappo AG, Gebiola M: Rickettsia symbionts cause parthenogenetic reproduction in the parasitoid wasp Pnigalio soemius (Hymenoptera: Eulophidae). Appl Environ Microbiol 2010 76(8):2589-2599

24. Perotti MA, Clarke HK, Turner BD, Braig HR: Rickettsia as obligate and mycetomic bacteria. Faseb J 2006, 20(13):2372-+.

25. Floate KD, Kyei-Poku GK, Coghlin PC: Overview and relevance of Wolbachia bacteria in biocontrol research. Biocontrol Science and Technology 2006, 16(8):767-788

26. Schaefer CW, Panizzi AR: Heteroptera of Economic Importance. Boca Raton, USA: CRC Press; 2000.

27. Perdikis D, Lykouressis D: Effects of various items, host plants, and temperatures on the development and survival of Macrolophus pygmaeus Rambur (Hemiptera: Miridae). Biol Control 2000, 17(1):55-60.

28. Vandekerkhove B, Van Baal E, Bolckmans K, De Clercq P: Effect of diet and mating status on ovarian development and oviposition in the polyphagous predator Macrolophus caliginosus (Heteroptera: Miridae). Biol Control 2006, 39(3):532-538

29. Machtelinckx T, Van Leeuwen T, Vanholme B, Gehesquiere B, Dermauw W, Vandekerkhove B, Gheysen G, De Clercq P: Wolbachia induces strong cytoplasmic incompatibility in the predatory bug Macrolophus pygmaeus. Insect Mol Biol 2009, 18(3):373-381.

30. Muyzer G, Dewaal EC, Uitterlinden AG: Profiling of complex microbia populations by denaturing gradient gel electrophoresis analysis of polymerase chain reaction amplified-genes coding for $16 \mathrm{~S}$ rRNA. Appl Environ Microbiol 1993, 59(3):695-700.

31. Torsvik V, Daae FL, Sandaa RA, Ovreas L: Novel techniques for analysing microbial diversity in natural and perturbed environments. Journal of Biotechnology 1998, 64(1):53-62.

32. Marzorati M, Alma A, Sacchi L, Pajoro M, Palermo S, Brusetti L, Raddadi N, Balloi A, Tedeschi $R$, Clementi $E$, et al: A novel Bacteroidetes symbiont is localized in Scaphoideus titanus, the insect vector of Flavescence Dorée in Vitis vinifera. Appl Environ Microbiol 2006, 72(2):1467-1475.

33. Gottlieb Y, Ghanim M, Chiel E, Gerling D, Portnoy V, Steinberg S, Tzuri G, Horowitz AR, Belausov E, Mozes-Daube N, et al: Identification and localization of a Rickettsia sp in Bemisia tabaci (Homoptera: Aleyrodidae). Appl Environ Microbiol 2006, 72(5):3646-3652

34. Zouache K, Voronin D, Tran-Van V, Mavingui P: Composition of bacterial communities associated with natural and laboratory populations of Asobara tabida infected with Wolbachia. Appl Environ Microbiol 2009, 75(11):3755-3764.

35. Martinez-Cascales JI, Cenis JL, Cassis G, Sanchez JA: Species identity of Macrolophus melanotoma (Costa 1853) and Macrolophus pygmaeus (Rambur 1839) (Insecta: Heteroptera: Miridae) based on morphological and molecular data and bionomic implications. Insect Syst Evol 2006, 37(4):385-404.

36. Rozen S, Skaletsky H: Primer3 on the WWW for general users and for biologist programmers. In Bioinformatics Methods and Protocols: Methods in Molecular Biology. NJ: Humana Press; Krawetz S, Misener S. Totowa 2000:365-386.

37. Altschul SF, Madden TL, Schaffer AA, Zhang JH, Zhang Z, Miller W, Lipman DJ: Gapped BLAST and PSI-BLAST: a new generation of protein database search programs. Nucleic Acids Res 1997, 25(17):3389-3402.

38. Hall TA: BioEdit: a user-friendly biological sequence alignment editor and analysis program for Windows $95 / 98 / N T$. Nucleic Acids Symposium Series 1999, 41:95-98. 
39. Huelsenbeck JP, Ronquist F: MRBAYES: Bayesian inference of phylogenetic trees. Bioinformatics 2001, 17(8):754-755.

40. Nylander JAA: MrModeltest v2. Program distributed by the author. Evolutionary Biology Centre, Uppsala University. 2004.

41. Page RD: TreeView: an application to display phylogenetic trees on personal computers. Comput Appl Biosci 1996, 12(4):357-358.

42. Janse I, Bok J, Zwart G: A simple remedy against artifactual double bands in denaturing gradient gel electrophoresis. Journal of Microbiological Methods 2004, 57(2):279-281.

43. Weisburg WG, Barns SM, Pelletier DA, Lane DJ: 16S Ribosomal DNA amplification for phylogenetic study. J Bacteriol 1991, 173(2):697-703.

44. Frank JA, Reich Cl, Sharma S, Weisbaum JS, Wilson BA, Olsen GJ: Critical evaluation of two primers commonly used for amplification of bacterial 16S rRNA genes. Appl Environ Microbiol 2008, 74(8):2461-2470.

45. Crotti E, Damiani C, Pajoro M, Gonella E, Rizzi A, Ricci I, Negri I, Scuppa P, Rossi P, Ballarini P, et al: Asaia, a versatile acetic acid bacterial symbiont, capable of cross-colonizing insects of phylogenetically distant genera and orders. Environ Microbiol 2009, 11(12):3252-3264.

46. Heddi A, Grenier AM, Khatchadourian C, Charles H, Nardon P: Four intracellular genomes direct weevil biology: Nuclear, mitochondrial, principal endosymbiont, and Wolbachia. Proc Natl Acad Sci U S A 1999, 96(12):6814-6819.

47. Moreira LA, Iturbe-Ormaetxe I, Jeffery JA, Lu GJ, Pyke AT, Hedges LM, Rocha BC, Hall-Mendelin S, Day A, Riegler M, et al: A Wolbachia symbiont in Aedes aegypti limits infection with Dengue, Chikungunya, and Plasmodium. Cell 2009, 139(7):1268-1278.

48. Vandekerkhove B, Parmentier L, Van Stappen G, Grenier S, Febvay G, Rey M, De Clercq P: Artemia cysts as an alternative food for the predatory bug Macrolophus pygmaeus. J Appl Entomol 2009, 133(2):133-142.

49. SPSS: User's Guide, version 17.0. Chicago, IL: SPSS Inc; 2008.

50. Lykouressis D, Giatropoulos A, Perdikis D, Favas C: Assessing the suitability of noncultivated plants and associated insect prey as food sources for the omnivorous predator Macrolophus pygmaeus (Hemiptera: Miridae). Biol Control 2008, 44(2):142-148

51. Perdikis D, Favas C, Lykouressis D, Fantinou A: Ecological relationships between non-cultivated plants and insect predators in agroecosystems: the case of Dittrichia viscosa (Asteraceae) and Macrolophus melanotoma (Hemiptera : Miridae). Acta Oecologica-International Journal of Ecology 2007, 31(3):299-306

52. Lopez I, Ruiz-Larrea F, Cocolin L, Orr E, Phister T, Marshall M, VanderGheynst J, Mills DA: Design and evaluation of PCR primers for analysis of bacterial populations in wine by denaturing gradient gel electrophoresis. Appl Environ Microbiol 2003, 69(11):6801-6807.

53. Graham Rl, Zahner V, Lucarotti CJ: An intracellular symbiont and other microbiota associated with field-collected populations of sawflies (Hymenoptera : Symphyta). Can J Microbiol 2008, 54(9):758-768.

54. Broderick NA, Raffa KF, Goodman RM, Handelsman J: Census of the bacterial community of the gypsy moth larval midgut by using culturing and culture-independent methods. Appl Environ Microbiol 2004, 70(1):293-300.

55. Dunn AK, Stabb EV: Culture-independent characterization of the microbiota of the ant lion Myrmeleon mobilis (Neuroptera : Myrmeleontidae). Appl Environ Microbiol 2005, 71(12):8784-8794.

56. Oliver KM, Moran NA, Hunter MS: Costs and benefits of a superinfection of facultative symbionts in aphids. Proc Biol Sci 2006, 273(1591):1273-1280

57. Cohen AC: Microbes in the diet setting. In Insect diets: science and technology. Boca Raton: CRC Press; Cohen AC 2004:225-248.

58. Ferree PM, Frydman HM, Li JM, Cao J, Wieschaus E, Sullivan W: Wolbachia utilizes host microtubules and Dynein for anterior localization in the Drosophila oocyte. PLoS Pathog 2005, 1(2):e14.

59. Chiel E, Inbar M, Mozes-Daube N, White JA, Hunter MS, Zchori-Fein E: Assessments of fitness effects by the facultative symbiont Rickettsia in the sweetpotato whitefly (Hemiptera: Aleyrodidae). Ann Entomol Soc Am 2009, 102(3):413-418.

60. Himler AG, Adachi-Hagimori T, Bergen JE, Kozuch A, Kelly SE, Tabashnik BE, Chiel E, Duckworth VE, Dennehy TJ, Zchori-Fein E, et al: Rapid spread of a bacterial symbiont in an invasive whitefly is driven by fitness benefits and female bias. Science 2011, 332(6026):254-256.

61. Vautrin $E$, Vavre $F$ : Interactions between vertically transmitted symbionts: cooperation or conflict? Trends in Microbiology 2009, 17(3):95-99.
62. Brownlie JC, Cass BN, Riegler M, Witsenburg JJ, Iturbe-Ormaetxe I, McGraw EA, O'Neill SL: Evidence for metabolic provisioning by a common invertebrate endosymbiont, Wolbachia pipientis, during periods of nutritional stress. PLoS Pathog 2009, 5(4):e1000368.

63. Teixeira L, Ferreira A, Ashburner M: The bacterial symbiont Wolbachia induces resistance to RNA viral infections in Drosophila melanogaster. PLOS Biol 2008, 6(12):e2.

64. Scarborough CL, Ferrari J, Godfray HCJ: Aphid protected from pathogen by endosymbiont. Science 2005, 310(5755):1781-1781.

65. Moran NA, Dunbar HE: Sexual acquisition of beneficial symbionts in aphids. Proc Natl Acad Sci U S A 2006, 103(34):12803-12806.

66. White JA, Kelly SE, Perlman SJ, Hunter MS: Cytoplasmic incompatibility in the parasitic wasp Encarsia inaron: disentangling the roles of Cardinium and Wolbachia symbionts. Heredity 2009, 102(5):483-489.

67. Chiel E, Zchori-Fein E, Inbar M, Gottlieb Y, Adachi-Hagimori T, Kelly SE, Asplen MK, Hunter MS: Almost there: transmission routes of bacterial symbionts between trophic levels. PLOS ONE 2009, 4(3):e4767.

68. Simon C, Frati F, Beckenbach A, Crespi B, Liu H, Flook P: Evolution, weighting, and phylogenetic utility of mitochondrial gene sequences and a compilation of conserved polymerase chain reaction primers. Ann Entomol Soc Am 1994, 87(6):651-701.

69. Relman DA, Schmidt TM, Macdermott RP, Falkow S: Identification of the uncultured Bacillus of Whipple's disease. New England Journal of Medicine 1992, 327(5):293-301.

70. Zhou W, Rousset F, O'Neill S: Phylogeny and PCR-based classification of Wolbachia strains using wsp gene sequences. Proc Biol Sci 1998, 265(1395):509-515.

doi:10.1186/1471-2180-12-S1-S9

Cite this article as: Machtelinckx et al:: Microbial community of predatory bugs of the genus Macrolophus (Hemiptera: Miridae). BMC Microbiology 2012 12(Suppl 1):S9.

\section{Submit your next manuscript to BioMed Central and take full advantage of:}

- Convenient online submission

- Thorough peer review

- No space constraints or color figure charges

- Immediate publication on acceptance

- Inclusion in PubMed, CAS, Scopus and Google Scholar

- Research which is freely available for redistribution
C Biomed Central 